\title{
Wetland birds of middle Vistula River during breeding season: the impact of human activities on the distribution, abundance and richness of species ${ }^{*}$
}

\section{Awifauna wodno-błotna środkowej Wisły w okresie lęgowym: wpływ działalności człow- ieka na rozmieszczenie, liczebność i bogactwo gatunkowe}

\author{
Dariusz Bukaciński', Monika Bukacińska², Arkadiusz Buczyński² \\ 1 Institute of Ecology and Bioethics, Cardinal Stefan Wyszyński University in Warsaw, Poland \\ ${ }^{2}$ Centre for Ecological Research in Dziekanów Leśny, Polish Academy of Sciences, Poland \\ ORCID: DB https://orcid.org/0000-0003-0163-2950; MB https://orcid.org/0000-0002-4526-3141; AB https://orcid.org/0000- \\ 0002-7577-4663•d.bukacinski@uksw.edu.pl
}

Abstract: The inventory of birds was conducted in the years 2005-2010 on the Vistula River section between Dęblin (km 388 of the river) and Podwierzbie ( $\mathrm{km} 435$ of the river). The study area includes a southern section of the European Ecological Natura 2000 Site in Poland PLB140004 "Middle Vistula River Valley" (IBA, PL083). On most areas the Vistula flows here within unregulated or relatively little modified riverbed, having features of a natural, lowland, braided river. Sandy islands and braid bars within a main channel, steep banks and old riparian afforestation create the unique breeding habitats of the Vistula River Valley. Especially the river channel habitats provide suitable breeding sites for many rare bird species, constituting for some of them the key-breeding sites. There are, however, fragments of several kilometres, where people transformed the Vistula River in a more noticeable way (Table 1). These are, among others: an urban section within Dęblin boundaries ( $k m 388$ to km 393 of the river), a fragment adjacent to Kozienice Power Plant ( $\mathrm{km} 421$ to km 426) and the area, where since 2007 gravel for industry has been mined from the river bottom ( $\mathrm{km} 426$ to $\mathrm{km} \mathrm{431).} \mathrm{The} \mathrm{aim} \mathrm{of} \mathrm{this} \mathrm{inventory} \mathrm{was} \mathrm{the} \mathrm{comparison} \mathrm{of} \mathrm{richness} \mathrm{and} \mathrm{abundance} \mathrm{of}$ breeding bird species linked directly to the river channel in fragments mentioned above. It will allow to estimate soberly how very the intensity of human utilization of the river affects the distribution of avifauna of the Vistula, determining the richness and abundance of valuable and/or endangered species breeding in a given area.

In the years 2007-2009 within a whole study area 32 breeding species characteristic for the riverbed and its surroundings were recorded. Among them 6 are threatened in Poland: mew gull (Larus canus), little tern (Sternula albifrons), ringed plover (Charadrius hiaticula), Eurasian oystercatcher (Haematopus ostralegus), corncrake (Crex crex) and hoopoe (Upupa epops) (Table 2a, b). The comparison of bird richness revealed significant differences between adjoining fragments of the river (Table 3). Decidedly the most valuable was the section between Wróble and Kozienice Power Plant (km 416-421). The Vistula River flows here within a riverbed only a little changed by man. It has an appearance typical for a large, lowland braided river with meandering channels, network of small side channels, steep banks, sandy bars and different kind of islands. Such differentiated environment is reflected in richness of birds. The association of 27-30 species reached here the total density of 337-397 pairs/km along the river, unparalleled in other habitats (Table 3). The urban section within Dęblin boundaries ( $\mathrm{km}$ 388-393) and a 5-kilometer-long area of gravel mining ( $\mathrm{km}$ 426-431) were much less attractive for birds. Straight, much narrower river channel, small number of islands in a main channel and a degraded valley in the vicinity of river banks caused, that only six to ten species nested there, of the total density ranged between 2.0-2.7 pairs $/ \mathrm{km}$ on the urban fragment and 3.8-6.6 pairs $/ \mathrm{km}$ within the gravel pit area (Table 3). However, these values are quite high in comparison

\footnotetext{
"This article was originally published in Polish as Dariusz Bukaciński, Monika Bukacińska, i Arkadiusz Buczyński. 2011. "Awifauna wodno-błotna środkowej Wisły w okresie lęgowym: wpływ działalności człowieka na rozmieszczenie, liczebność i bogactwo gatunkowe." Studia Ecologiae et Bioethicae 9(2): 68-86. The translation of the article into English was financed by the Ministry of Science and Higher Education of the Republic of Poland as part of the activities promoting science - Decision No. 676/P-DUN/2019 of 2 April 2019. Translation made by GROY Translations.
} 
to those recorded for the fragment adjoining Kozienice Power Plant ( $\mathrm{km}$ 421-426). The river channel is here clearly contracted and the bottom is deepened. The river flows fast within one channel. Numerous, concrete, submerged groynes, revetments on both sides of the river and a bank made of concrete, protecting a power station are very characteristic for this place. Such a man-made environment almost excludes the possibility of breeding of birds within a riverbed. Only single pairs of lapwings (Vanellus vanellus), common sandpipers (Actitis hypoleucos), little ringed plovers (Charadrius dubius) and goosanders (Mergus merganser) occurred here, sporadically also common terns (Sterna hirundo) (Table 2a,b). The total density was very low and did not exceed $1.5 \mathrm{pairs} / \mathrm{km}$ along the river.

The yearly surveys of birds in the years previous to and after beginning of a gravel and sand mining from the river bottom allowed to estimate if the development had changed somehow the status of riparian bird populations. During three years of an activity a negative impact of the development on the richness and abundance of bird species was not recorded, both in direct vicinity and on the fragment below (Table 4). Not the small harmfulness of the development finally influences the status and changes of avifauna in these sections, but the place where it is situated. It should be kept in mind that the sand mining takes place only within $2 \mathrm{~km}$ of the section of Vistula that is regulated to a large degree, and the section above is almost unavailable for riparian birds (Kozienice Power Station). One can assume with high probability bordering on certainty that when the gravel excavation took place on the fragment between $\mathrm{km} 393$ and $\mathrm{km} 421$ or below $\mathrm{km} 431$ of the river, the negative impact of the development on breeding habitats and avifauna of the river channel would be much more noticeable and worse still - it would be irreversible. Both fragments mentioned above are now unique places, where the bird association characteristic for the unregulated channel of lowland river can be found - the environment, which irrevocably declines due to human activities.

Keywords: avifauna of Vistula River, threats for riparian birds, river regulation, gravel and sand mining

Streszczenie: Monitoring ptaków prowadzono w latach 2005-2010 na fragmencie rzeki między Dęblinem (388 km rzeki) i Podwierzbiem (435 km). Obejmuje on południową część Europejskiej ostoi Natura 2000 PLB140004 „Dolina Środkowej Wisły” (ostoi IBA, PL083). Na przeważającym obszarze Wisła płynie tu nieregulowanym lub przekształconym jedynie w niewielkim stopniu korycie, mając charakter nizinnej rzeki roztokowej. Unikalnymi siedliskami lęgowymi doliny Wisły są piaszczyste wyspy i ławice w nurcie, urwiste brzegi oraz stare zadrzewienia łęgowe. Zwłaszcza siedliska nurtu rzeki dostarczają dogodnych miejsc gniazdowania dla wielu rzadkich gatunków ptaków, stanowiąc dla niektórych z nich kluczowe lęgowisko w kraju. Są jednak i kilkukilometrowe fragmenty, gdzie Wisła została przekształcona przez człowieka w sposób bardziej widoczny. Do takich należą między innymi: miejski odcinek rzeki na wysokości Dęblina (388-393 km rzeki) oraz fragment na wysokości Elektrowni Kozienice (421-425 km) oraz obszar, gdzie od 2007 roku wydobywane jest z dna rzeki kruszywo na cele gospodarcze (426-430 km).

Celem monitoringu było porównanie składu i liczebności lęgowych gatunków ptaków związanych z korytem rzeki na wymienionych odcinakach Wisły. Pozwoli to realnie ocenić na ile intensywność wykorzystania Wisły przez człowieka wpływa na rozmieszczenie ornitofauny w dolinie Wisły, decydując o różnorodności gatunkowej i liczbie gatunków cennych i/lub zagrożonych gnieżdżących się w danym miejscu.

W latach 2007-2009 badań na całym fragmencie Wisły objętym badaniami stwierdzono obecność 32 gatunków ptaków charakterystycznych dla koryta i doliny rzeki. Wśród nich było 6 gatunków zagrożonych wyginięciem w skali kraju: mewa siwa (Larus canus), rybitwa białoczelna (Sternula albifrons), sieweczka obrożna (Charadrius hiaticula), ostrygojad (Haematopus ostralegus), derkacz (Crex crex) i dudek (Upupa epops). Porównanie składu gatunkowego awifauny pokazuje duże różnice między sąsiadującymi ze sobą odcinkami rzeki. Zdecydowanie najcenniejszym był fragment między Wróblami i Elektrownią Kozienice (416-420 km). Wisła płynie tu korytem tylko w niewielkim stopniu zmienionym. Ma charakter typowy dla dużej, nizinnej rzeki roztokowej z licznymi odnogami, urwistymi brzegami, ławicami piachu i wyspami o różnym charakterze. Tak zróżnicowane środowisko ma swoje odzwierciedlenie w różnorodności gatunkowej ptaków. Zespół 27-30 gatunków osiągał tu, niespotykane w innych środowiskach, zagęszczenie 337-397 par/km biegu rzeki. Miejski fragment rzeki na wysokości Dęblina (388-393 km rzeki) i 5-kilometrowy obszar wydobywania kruszywa z dna Wisły $(425-430 \mathrm{~km})$ były dla ptaków o wiele mniej atrakcyjne. Proste, dużo wężzze koryto, mała liczba wysp w nurcie i zdegradowana dolina rzeki w bezpośredniej bliskości brzegów powodowała, że gnieździło się tutaj od 6 do 10 gatunków ptaków, których zagęszczenie wahało się od 2,0-2,7 par/km rzeki na odcinku miejskim, do 3,8-6,6 par/ km rzeki na fragmencie rzeki, gdzie wydobywane było kruszywo. Wartości te są jednak i tak wysokie, w porównaniu ze stanem odnotowanym na wysokości Elektrowni Kozienice (420-425 km rzeki). Koryto jest tu wyraźnie zwężone i pogłębione, rzeka płynie wartko jedną strugą, a charakterystycznym elementem w nurcie są liczne betonowe ostrogi i opaski po obu stronach rzeki oraz betonowy brzeg chroniący Elektrownię. Taki obraz wyklucza niemal zupełnie możliwość gniazdowania ptaków w korycie. Spotyka się tutaj jedynie pojedyncze pary czajki (Vanellus vanellus), piskliwca (Actitis hypoleucos), sieweczki rzecznej (Charadrius dubius), nurogęsia (Mergus merganser), a wyjątkowo również rybitwy rzecznej (Sterna hirundo). Zagęszczenie zespołu ptaków jest bardzo niskie i nie przekracza zazwyczaj 1,5 par/km rzeki. Coroczny monitoring ptaków w latach poprzedzających i już po rozpoczęciu 
wydobywania kruszywa z dna rzeki pozwolił ocenić czy inwestycja ta w jakikolwiek sposób zmieniła obraz awifauny. W ciągu trzech lat przedsięwzięcia nie zanotowano negatywnego wpływu inwestycji na różnorodność gatunkową i liczebność ornitofauny tak w bezpośrednim otoczeniu, jak na fragmencie rzeki poniżej. Na obraz i zmiany ornitofauny tych miejsc w decydującym stopniu wpływa nie tyle mała szkodliwość rodzaju inwestycji, co miejsce jej usytuowania. Należy przypomnieć, że pobór kruszywa odbywa się jedynie na odcinku dwóch kilometrów, w dużym stopniu uregulowanej rzeki, a fragment rzeki bezpośrednio powyżej praktycznie jest niedostępny dla ptaków (Elektrownia Kozienice). Z prawdopodobieństwem graniczącym z pewnością można założyć, że w sytuacji, kiedy pobór kruszywa odbywałby się na fragmencie rzeki między $394-420 \mathrm{~km}$ lub poniżej 431 km szlaku wodnego negatywny wpływ na siedliska lęgowe i awifaunę koryta rzeki byłby bardzo dobrze widoczny i co gorsze - zapewne nieodwracalny. Oba wymienione wyżej fragmenty są obecnie unikalnym już miejscem, gdzie można spotkać zespół ptaków charakterystyczny dla koryta nieuregulowanej rzeki nizinnej - środowiska, które w związku z działalnością człowieka bezpowrotnie zanika.

Słowa kluczowe: ptaki Wisły, zagrożenia awifauny rzek, regulacja rzek, pobór kruszywa

\section{Introduction}

The European IBA (Important Bird Area) "Middle Vistula River Valley" (PL 083 Poland) covers more than $260 \mathrm{~km}$ of the Vistula River between Puławy (km 370 of the waterway) and Płock (km 632 of the river). The area was included in the Natura 2000 network as a special protection area (SPA) - Middle Vistula River Valley, PLB140004 (Sidło et al. 2004). The section of the river between $\mathrm{km} 388$ to $\mathrm{km} 435$ of the waterway covers the southern part of this bird sanctuary. For the most part, the Vistula flows here within unregulated or relatively little modified riverbed, exhibiting features of a lowland braided river. Sandy beaches and bars in the channel, steep banks and old riparian afforestation form unique sites in the valley. River channel habitats provide suitable nesting sites for many rare bird species, providing for some of them the key-breeding site in the country. However, there are fragments of several kilometres, where people transformed the river in a more noticeable way. An example of this is an urban section of the river within Dęblin boundaries or its fragment adjacent to the Kozienice Power Plant (Table 1).

The aim of this paper is to compare the composition and abundance of breeding bird species linked with the riverbed in the aforementioned sections of the Vistula. We also wanted to check whether the start of gravel and sand mining from the bottom of the river below the Kozienice Power Plant (from km 426 to $\mathrm{km} \mathrm{431,} \mathrm{Table} \mathrm{1)} \mathrm{would}$ affect the number and diversity of the birds there. A comparison of the breeding avifauna of different sites transformed by man to varying degrees will also allow us to assess to what extent the character of a given site determines the distribution of valuable and endangered species.

\section{Material and methods}

The inventory included bird species inhabiting islands and bars in the channel and the valley in the immediate vicinity of the river (up to $50 \mathrm{~m}$ from the river). Special attention was paid to the presence of species listed in Annex I of the Birds Directive, in the Polish Red Book of Animals, and recognised as valorising Special Protection Areas of Natura 2000 (SPAs) in Poland (Głowaciński 2001, Gromadzki 2004).

The number and distribution of birds inhabiting islands, bars and steep banks were determined according to the standard method of riverbed avifauna monitoring, which involves carrying out two surveys (boating expeditions) (e.g. Wesołowski et al. 1984; Bukaciński et al. 1994; Keller et al. 2000). The large width and braided character of the river meant that, in addition to the survey of the main channel, a lot of attention was paid to checking the side channels which were usually characterised by islands and peninsulas with heavy vegetation. For some species (e.g. the common sandpiper, little ringed plover, or sand martin) these sites are as important as the islands in the channel (e.g. 
Dombrowski et al. 1994). We navigated the river in an inflatable motor boat. During the boating expedition, every larger island and bar was inspected on foot, with nesting sites, families with young, mating or anxious birds were recorded on 1:15,000 scale topographic maps. The steep riverbanks (counting the nesting burrows) and small, flat, sandy bars were inspected directly from the boat.

Table 1. Characteristics of studied 5-km-long fragments of the Vistula River.

\begin{tabular}{|c|c|c|}
\hline $\begin{array}{l}\text { Border } \\
\text { locations } \\
\text { and the kilometres } \\
\text { of the river }\end{array}$ & $\begin{array}{l}\text { Type and extent of transformation } \\
\text { of the inter-embankment zone }\end{array}$ & Riverbed characteristics \\
\hline $\begin{array}{l}\text { Dęblin } \\
\text { km } 388 \text { to } \mathrm{km} 393\end{array}$ & $\begin{array}{l}\text { Urban section, regulated } \\
\text { to a large degree. } \\
\text { A number of hydrotechnical facilities } \\
\text { constructed along the entire length } \\
\text { of the river: groynes, revetments, } \\
\text { bridges, reinforcements of the banks } \\
\text { with concrete or rubble. }\end{array}$ & $\begin{array}{l}\text { A straight, deep, narrow riverbed } \\
\text { with a small number of islands } \\
\text { situated only near the banks of the } \\
\text { river; sandy bars only in the borderline } \\
\text { sections and sand depositions } \\
\text { between the groynes }\end{array}$ \\
\hline $\begin{array}{l}\text { Wróble-Kochów } \\
\text { km } 416 \text { to km } 421\end{array}$ & $\begin{array}{l}\text { A fragment slightly changed by man. } \\
\text { Single groynes and dams. }\end{array}$ & $\begin{array}{l}\text { Wide, shallow and winding with } \\
\text { a large number of channels; the river } \\
\text { flows in several channels. A large } \\
\text { number of very diverse islands and } \\
\text { bars in the channel. Banks are usually } \\
\text { earthy, often steep, naturally sinking. }\end{array}$ \\
\hline $\begin{array}{l}\text { Kochów-Świerże } \\
\text { Górne (Kozienice } \\
\text { Power Plant) } \\
\text { km } 421 \text { to km } 426\end{array}$ & $\begin{array}{l}\text { Transformed and regulated } \\
\text { to a large degree: } \\
\text { a large number of densely distributed } \\
\text { groynes and river walls on both banks, } \\
\text { with large sections of the banks } \\
\text { being reinforced with concrete. }\end{array}$ & $\begin{array}{l}\text { Straight, deep and narrow, no islands } \\
\text { or bars in the channel. Few, strongly } \\
\text { overgrown peninsulas and depositions } \\
\text { between the groynes, no periodically } \\
\text { appearing sandy bars. }\end{array}$ \\
\hline $\begin{array}{l}\text { Świerże Górne- } \\
\text { Pasternik } \\
\text { (Radomka } \\
\text { River mouth) } \\
\text { km } 426 \text { to km } 431\end{array}$ & $\begin{array}{l}\text { River bottom used for gravel } \\
\text { and sand mining. A fewer number } \\
\text { of hydrotechnical facilities, with only } \\
\text { single groynes and river walls; } \\
\text { some sections of the banks locally } \\
\text { reinforced with rubble or concrete. }\end{array}$ & $\begin{array}{l}\text { A medium width riverbed } \\
\text { of variable depth. In the lower part of } \\
\text { the section the presence of individual } \\
\text { islands at the shores, sandy bars } \\
\text { and side channels. }\end{array}$ \\
\hline $\begin{array}{l}\text { Pasternik- } \\
\text { Podwierzebie } \\
\text { km } 431 \text { to km } 436\end{array}$ & $\begin{array}{l}\text { A fragment slightly changed by man. } \\
\text { Single groynes, some sections of the } \\
\text { banks locally reinforced with rubble. }\end{array}$ & $\begin{array}{l}\text { Wide, quite shallow, with few } \\
\text { channels. River flowing in several } \\
\text { channels. A small number of large, } \\
\text { usually islands with heavy vegetation; } \\
\text { presence of sandy bars in the channel. }\end{array}$ \\
\hline
\end{tabular}


The survey dates were attempted to be set in the optimal period, taking into account the breeding phenology of individual bird species and the current dynamics of the river levels. The first boating expedition usually took place in the first half of May. The counts included the species which began to reproduce the earliest, including mainly gulls, ducks and most charadriiformes and birds of prey. During the second survey, which usually took place in the first or second decade of June, the number of terns, sand martins, common sandpipers, common kingfishers, and ducks with the young (mainly goosanders) was monitored. An important supplement to the results from the boating expedition was the repeated monitoring of selected (larger) islands and bars, which was carried out annually in the April-July period as part of activities aimed at active protection of the endangered bird species. Although every effort has been made to carry out the monitoring as accurately as possible, the resulting assessments of abundance are usually subject to some error. Most often the numbers of birds are underestimated due to more difficult species detection (e.g. ducks) or the specificity of the method that prevents full registration of breeding sites (most passerines). In situations where we were not sure of the exact number of given species, we estimated it by giving a range of minimum and maximum values. This way we reduced the possible error to a minimum.

In this paper we will present the results of monitoring mainly from 2007 and 2009, characterising the species composition, abundance and general density of birds in the specified five-kilometre-long fragments of the river, differing in the degree of transformation and use of the valley by man. For the sections of the river where gravel and sand were mined, the results of monitoring in 2005, 2008 and 2010 are also presented. The threatened species are those listed in the last edition of the Polish Red Book of Animals (Głowaciński 2001), vulnerable in Europe (corncrake and hoopoe) and the mew gull
(Larus canus, not long ago referred to as the common gull), which in the last quarter of the century has recorded a drastic decline in Poland (Bukaciński, and Bukacińska 2003, 2007, 2009).

\section{Habitat and faunistic characteristics of selected fragments of the Vistula River}

In 2007 and 2009, a total of 32 bird species characteristic for the riverbed and valley were found on the studied parts of the middle Vistula. Among them there were six species threatened on a nation-wide scale, i.e. the mew gull, little tern, ringed plover, Eurasian oystercatcher, corncrake and hoopoe (Table 2a, b). The analysis of the species composition and abundance of avifauna in adjacent parts of the river shows large differences in the species diversity of these sites (Table $2 \mathrm{a}, \mathrm{b}$, Table 3 ). Detailed habitat and faunistic characteristics of these sites are presented below.

\subsection{The urban section of the river in Dęblin ( $\mathrm{km} 388$ to km 393)}

The Vistula flows here along a straight, not very wide (300-400 m) channel. Few islands with heavy vegetation, including trees and/or willow and poplar shrubs are located close to the riverbanks. At low water levels, non-durable sandy bars appear on the border kilometres of the section (Table 1). The composition of the breeding avifauna of this site is equally determined by the habitat specificity of the river, as well as by the increased human interference associated primarily with individual tourism, urban noise and inland navigation. In 2007 and 2009, only 6-8 species of birds were nesting there, at a total density not exceeding 2.7 pairs $/ \mathrm{km}$ along the river (Table $2 a, b$, Table 3 ). However, it is worth noting that the presence of low sandy bars in the channel allowed for the presence of two endangered species: the little tern and the ringed plover (Table 2a, b). However, the total density of these species is very low, 0.5-0.6 pairs/ $\mathrm{km}$ and never higher than 1.0 pairs $/ \mathrm{km}$ along the river (Table 3 ). 
Table 2. Abundance of bird species characteristic for middle Vistula River Valley, on chosen fragments of the river. Threatened species are bolded (a) in 2007, (b) in 2009.

\begin{tabular}{|c|c|c|c|c|c|}
\hline \multirow[b]{2}{*}{2007} & \multicolumn{4}{|c|}{ River characteristics } & \multirow[b]{2}{*}{$\begin{array}{c}\text { Natural, } \\
\text { below } \\
\text { the } \\
\text { development }\end{array}$} \\
\hline & $\begin{array}{l}\text { Urban - } \\
\text { - Dęblin }\end{array}$ & $\begin{array}{c}\text { Natural - } \\
\text { above the } \\
\text { development }\end{array}$ & $\begin{array}{l}\text { Completely } \\
\text { transformed - } \\
\text { Kozienice } \\
\text { Power Plant }\end{array}$ & $\begin{array}{l}\text { Development } \\
\quad=\text { sand } \\
\text { extraction } \\
\text { from riverbed }\end{array}$ & \\
\hline Species & $\begin{array}{l}\mathrm{km} 388 \\
\text { to } \mathrm{km} 393\end{array}$ & $\begin{array}{l}\mathrm{km} 416 \\
\text { to } \mathrm{km} 420\end{array}$ & $\begin{array}{l}\mathrm{km} 421 \\
\text { to } \mathrm{km} 425\end{array}$ & $\begin{array}{l}\mathrm{km} 426 \\
\text { to } \mathrm{km} 430\end{array}$ & $\begin{array}{l}\mathrm{km} 431 \\
\text { to } \mathrm{km} 435\end{array}$ \\
\hline $\begin{array}{l}\text { Black-headed gull } \\
\text { Chroicocephalus ridibundus }\end{array}$ & 0 & $1400-1600$ & 0 & 0 & 0 \\
\hline $\begin{array}{l}\text { Mediterranean gull } \\
\text { Ichthyaeus melanocephalus }\end{array}$ & 0 & 1 & 0 & 0 & 0 \\
\hline $\begin{array}{l}\text { Mew gull } \\
\text { Larus canus }\end{array}$ & $1-2$ & 62 & $\mathbf{0}$ & $\mathbf{0}$ & 2 \\
\hline $\begin{array}{l}\text { Common tern } \\
\text { Sterna hirundo }\end{array}$ & 5 & $65-75$ & $2-4$ & 0 & $20-30$ \\
\hline $\begin{array}{l}\text { Little tern } \\
\text { Sternula albifrons }\end{array}$ & $2-3$ & $17-22$ & $\mathbf{0}$ & $\mathbf{0}$ & $10-12$ \\
\hline $\begin{array}{l}\text { Little ringed plover } \\
\text { Charadrius dubius }\end{array}$ & 1 & $5-7$ & 1 & 4 & 4 \\
\hline $\begin{array}{l}\text { Ringed plover } \\
\text { Charadrius hiaticula }\end{array}$ & $\mathbf{0}$ & $8-9$ & $\mathbf{0}$ & 3 & 1 \\
\hline $\begin{array}{l}\text { Lapwing } \\
\text { Vanellus vanellus }\end{array}$ & 1 & $3-5$ & 1 & 3 & 2 \\
\hline $\begin{array}{l}\text { Common redshank } \\
\text { Tringa totanus }\end{array}$ & $0-1$ & 1 & 0 & 4 & 2 \\
\hline $\begin{array}{l}\text { Eurasian oystercatcher } \\
\text { Haematopus ostralegus }\end{array}$ & $\mathbf{0}$ & 1 & $\mathbf{0}$ & $\mathbf{0}$ & $\mathbf{0}$ \\
\hline $\begin{array}{l}\text { Common sandpiper } \\
\text { Actitis hypoleucos }\end{array}$ & $1-2$ & $6-7$ & 1 & 1 & $1-2$ \\
\hline $\begin{array}{l}\text { Black-tailed godwit } \\
\text { Limosa limosa }\end{array}$ & 0 & 1 & 0 & 1 & 1 \\
\hline $\begin{array}{l}\text { Mallard } \\
\text { Anas platyrhynchos }\end{array}$ & 0 & $10-12$ & 0 & $2-3$ & $4-6$ \\
\hline $\begin{array}{l}\text { Gadwall } \\
\text { Anas strepera }\end{array}$ & 0 & $1-2$ & 0 & 0 & $1-2$ \\
\hline $\begin{array}{l}\text { Garganey } \\
\text { Anas querquedula }\end{array}$ & 0 & 1 & 0 & 0 & 2 \\
\hline $\begin{array}{l}\text { Northern shoveler } \\
\text { Anas clypeata }\end{array}$ & 0 & 1 & 0 & 0 & 0 \\
\hline $\begin{array}{l}\text { Tufted duck } \\
\text { Aythya fuligula }\end{array}$ & 0 & 1 & 0 & 0 & 0 \\
\hline $\begin{array}{l}\text { Goosander } \\
\text { Mergus merganser }\end{array}$ & $1-2$ & $2-4$ & 3 & 1 & 2 \\
\hline
\end{tabular}




\begin{tabular}{|l|c|c|c|c|c|}
\hline $\begin{array}{l}\text { Corncrake } \\
\text { Crex crex }\end{array}$ & $\mathbf{0}$ & $\mathbf{2}$ & $\mathbf{0}$ & $\mathbf{0}$ & $\mathbf{2}$ \\
\hline $\begin{array}{l}\text { Western marsh harrier } \\
\text { Circus aeruginosus }\end{array}$ & 0 & 0 & 0 & 0 & 1 \\
\hline $\begin{array}{l}\text { Long-eared owl } \\
\text { Asio otus }\end{array}$ & 0 & 1 & 0 & 0 & 0 \\
\hline $\begin{array}{l}\text { Hoopoe } \\
\text { Upupa epops }\end{array}$ & $\mathbf{0}$ & $\mathbf{1}$ & $\mathbf{0}$ & $\mathbf{0}$ & $\mathbf{1}$ \\
\hline $\begin{array}{l}\text { River warbler } \\
\text { Locustella fluviatilis }\end{array}$ & 0 & $2-3$ & 0 & 0 & 2 \\
\hline $\begin{array}{l}\text { Common kingfisher } \\
\text { Alcedo atthis }\end{array}$ & 0 & $1-2$ & 0 & 0 & 1 \\
\hline $\begin{array}{l}\text { Sand martin } \\
\text { Riparia riparia }\end{array}$ & 0 & $160-170$ & 0 & 0 & 1 \\
\hline $\begin{array}{l}\text { European green woodpecker } \\
\text { Picus viridis }\end{array}$ & 0 & 2 & 0 & 0 & 0 \\
\hline $\begin{array}{l}\text { Black woodpecker } \\
\text { Dryocopus martius }\end{array}$ & 0 & $3-5$ & 0 & 0 & 0 \\
\hline $\begin{array}{l}\text { Eurasian penduline tit } \\
\text { Remiz pendulinus }\end{array}$ & 0 & 1 & 0 & 0 & \\
\hline
\end{tabular}

\begin{tabular}{|c|c|c|c|c|c|}
\hline \multirow{2}{*}{$\begin{array}{l}\text { (b) } \\
2009\end{array}$} & \multicolumn{4}{|c|}{ River characteristics } & \multirow[b]{2}{*}{$\begin{array}{l}\text { Natural, } \\
\text { below } \\
\text { the } \\
\text { development }\end{array}$} \\
\hline & $\begin{array}{l}\text { Urban - } \\
\text { - Dęblin }\end{array}$ & $\begin{array}{c}\text { Natural - } \\
\text { above the } \\
\text { development }\end{array}$ & $\begin{array}{c}\text { Completely } \\
\text { transformed - } \\
\text { Kozienice } \\
\text { Power Plant }\end{array}$ & $\begin{array}{l}\text { Development } \\
\quad=\text { sand } \\
\text { extraction } \\
\text { from riverbed }\end{array}$ & \\
\hline Species & $\begin{array}{l}\mathrm{km} 388 \\
\text { to } \mathrm{km} 393\end{array}$ & $\begin{array}{l}\mathrm{km} 416 \\
\text { to } \mathrm{km} 420\end{array}$ & $\begin{array}{l}\mathrm{km} 421 \\
\text { to } \mathrm{km} 425\end{array}$ & $\begin{array}{l}\mathrm{km} 426 \\
\text { to } \mathrm{km} 430\end{array}$ & $\begin{array}{l}\mathrm{km} 431 \\
\text { to } \mathrm{km} 435\end{array}$ \\
\hline $\begin{array}{l}\text { Black-headed gull } \\
\text { Chroicocephalus ridibundus }\end{array}$ & 0 & $1500-1800$ & 0 & 0 & 0 \\
\hline $\begin{array}{l}\text { Caspian gull } \\
\text { Larus cachinnans }\end{array}$ & 0 & 1 & 0 & 0 & 0 \\
\hline $\begin{array}{l}\text { Mediterranean gull } \\
\text { Ichthyaeus melanocephalus }\end{array}$ & 0 & $1-2$ & 0 & 0 & 0 \\
\hline $\begin{array}{l}\text { Mew gull } \\
\text { Larus canus }\end{array}$ & $\mathbf{0}$ & 36 & $\mathbf{0}$ & 1 & 2 \\
\hline $\begin{array}{l}\text { Common tern } \\
\text { Sterna hirundo }\end{array}$ & 2 & $35-41$ & 0 & $10-12$ & $23-28$ \\
\hline $\begin{array}{l}\text { Little tern } \\
\text { Sternula albifrons }\end{array}$ & 5 & $7-11$ & 0 & 5 & $10-12$ \\
\hline $\begin{array}{l}\text { Little ringed plover } \\
\text { Charadrius dubius }\end{array}$ & 1 & $15-18$ & 1 & $0-1$ & $1-2$ \\
\hline
\end{tabular}




\begin{tabular}{|c|c|c|c|c|c|}
\hline $\begin{array}{l}\text { Ringed plover } \\
\text { Charadrius hiaticula }\end{array}$ & 1 & $13-14$ & 0 & 0 & 3 \\
\hline $\begin{array}{l}\text { Lapwing } \\
\text { Vanellus vanellus }\end{array}$ & 0 & 5 & 1 & 2 & $11-12$ \\
\hline $\begin{array}{l}\text { Common redshank } \\
\text { Tringa totanus }\end{array}$ & 0 & 3 & 0 & 1 & 1 \\
\hline $\begin{array}{l}\text { Eurasian oystercatcher } \\
\text { Haematopus ostralegus }\end{array}$ & 0 & 2 & 0 & 0 & 0 \\
\hline $\begin{array}{l}\text { Common sandpiper } \\
\text { Actitis hypoleucos }\end{array}$ & 1 & $9-10$ & $0-1$ & $0-1$ & $2-3$ \\
\hline $\begin{array}{l}\text { Black-tailed godwit } \\
\text { Limosa limosa }\end{array}$ & 0 & 1 & 0 & 0 & 0 \\
\hline $\begin{array}{l}\text { Mallard } \\
\text { Anas platyrhynchos }\end{array}$ & 0 & 24-29 & 0 & $4-5$ & 8 \\
\hline $\begin{array}{l}\text { Gadwall } \\
\text { Anas strepera }\end{array}$ & 0 & $2-3$ & 0 & 0 & 0 \\
\hline $\begin{array}{l}\text { Garganey } \\
\text { Anas querquedula }\end{array}$ & 0 & $2-4$ & 0 & 0 & 1 \\
\hline $\begin{array}{l}\text { Northern shoveler } \\
\text { Anas clypeata }\end{array}$ & 0 & $1-2$ & 0 & 0 & 0 \\
\hline $\begin{array}{l}\text { Tufted duck } \\
\text { Aythya fuligula }\end{array}$ & 0 & $2-3$ & 0 & 0 & 0 \\
\hline $\begin{array}{l}\text { Goosander } \\
\text { Mergus merganser }\end{array}$ & 2 & 4-5 & 1 & 2 & $1-2$ \\
\hline $\begin{array}{l}\text { Common goldeneye } \\
\text { Bucephala clangula }\end{array}$ & 0 & $0-1$ & 0 & 0 & $0-1$ \\
\hline $\begin{array}{l}\text { Corncrake } \\
\text { Crex crex }\end{array}$ & 0 & 0 & 0 & 0 & $3-4$ \\
\hline $\begin{array}{l}\text { Western marsh harrier } \\
\text { Circus aeruginosus }\end{array}$ & 0 & 0 & 0 & 0 & 1 \\
\hline $\begin{array}{l}\text { Eurasian hobby } \\
\text { Falco subbuteo }\end{array}$ & 0 & 1 & 0 & 0 & 0 \\
\hline $\begin{array}{l}\text { Common kestrel } \\
\text { Falco tinnunculus }\end{array}$ & 0 & 1 & 0 & 1 & 0 \\
\hline $\begin{array}{l}\text { Long-eared owl } \\
\text { Asio otus }\end{array}$ & 0 & 1 & 0 & 0 & 0 \\
\hline $\begin{array}{l}\text { Hoopoe } \\
\text { Upupa epops }\end{array}$ & 0 & 2 & 0 & 0 & $0-1$ \\
\hline $\begin{array}{l}\text { River warbler } \\
\text { Locustella fluviatilis }\end{array}$ & 0 & $1-2$ & 0 & 0 & $2-3$ \\
\hline $\begin{array}{l}\text { Common kingfisher } \\
\text { Alcedo atthis }\end{array}$ & 0 & 1 & 0 & 0 & 0 \\
\hline $\begin{array}{l}\text { Sand martin } \\
\text { Riparia riparia }\end{array}$ & 0 & 22 & 0 & 0 & $765-925$ \\
\hline $\begin{array}{l}\text { European green woodpecker } \\
\text { Picus viridis }\end{array}$ & 0 & 2 & 0 & 0 & 1 \\
\hline $\begin{array}{l}\text { Black woodpecker } \\
\text { Dryocopus martius }\end{array}$ & 0 & 2 & 0 & 0 & 1 \\
\hline $\begin{array}{l}\text { Eurasian penduline tit } \\
\text { Remiz pendulinus }\end{array}$ & 0 & 4-5 & 0 & 0 & 2 \\
\hline
\end{tabular}


Table 3. Number and density of species (number of pairs/ $\mathrm{km}$ along the river) of wetland birds on 5-km-long fragments of the Vistula River, transformed by man to different degrees. Data regarding the section where the sand has been excavated from the riverbed since 2007 are bolded.

(a)

\begin{tabular}{|c|c|c|c|c|}
\hline \multirow[b]{2}{*}{$\begin{array}{l}\text { Characteristics and the } \\
\text { kilometers of the Vistula }\end{array}$} & \multicolumn{2}{|c|}{ Number of species } & \multicolumn{2}{|c|}{ Nest density / river $\mathrm{km}^{1}$} \\
\hline & All & Endangered & All species & $\begin{array}{l}\text { Endangered } \\
\text { species }\end{array}$ \\
\hline $\begin{array}{l}\text { Urban, regulated, } \\
\text { km } 388 \text { to } \mathrm{km} 393\end{array}$ & $7-8$ & 1 & $2.0-2.7$ & $0.5-0.8$ \\
\hline $\begin{array}{c}\text { Natural, } \\
\mathrm{km} 416 \text { to } \mathrm{km} 420\end{array}$ & 27 & 6 & $39.6-45.6$ & $18.2-19.4$ \\
\hline $\begin{array}{l}\text { Regulated, power plant, } \\
\text { km } 421 \text { to km } 425\end{array}$ & 5 & 0 & $1.6-2.0$ & 0 \\
\hline $\begin{array}{l}\text { Sand extraction, } \\
\text { km } 426 \text { to } \mathrm{km} 430\end{array}$ & 8 & 1 & $3.8-4.0$ & 0.6 \\
\hline $\begin{array}{c}\text { Natural, } \\
\text { km } 431 \text { to } \mathrm{km} 435\end{array}$ & 21 & 5 & $12.4-15.8$ & $3.2-3.6$ \\
\hline
\end{tabular}

(b)

\begin{tabular}{|c|c|c|c|c|}
\hline \multirow[b]{2}{*}{$\begin{array}{l}\text { Characteristics and the } \\
\text { kilometers of the Vistula }\end{array}$} & \multicolumn{2}{|c|}{ Number of species } & \multicolumn{2}{|c|}{ Nest density / river $\mathrm{km}^{1}$} \\
\hline & All & Endangered & All species & $\begin{array}{l}\text { Endangered } \\
\text { species }\end{array}$ \\
\hline $\begin{array}{l}\text { Urban, regulated, } \\
\mathrm{km} 388 \text { to } \mathrm{km} 393\end{array}$ & 6 & 2 & 2.0 & 1.0 \\
\hline $\begin{array}{c}\text { Natural, } \\
\mathrm{km} 416 \text { to } \mathrm{km} 420\end{array}$ & $29-30$ & 5 & $32.6-37.8$ & $11.8-13.0$ \\
\hline $\begin{array}{l}\text { Regulated, power plant, } \\
\text { km } 421 \text { to km } 425\end{array}$ & $2-3$ & 0 & $0.6-0.8$ & 0 \\
\hline $\begin{array}{l}\text { Sand extraction, } \\
\text { km } 426 \text { to } \mathrm{km} 430\end{array}$ & $9-10$ & 2 & $5.4-6.6$ & 1.2 \\
\hline $\begin{array}{c}\text { Natural, } \\
\text { km } 431 \text { to } \mathrm{km} 435\end{array}$ & $18-20$ & $4-5$ & $13.8-16.8$ & $3.6-4.4$ \\
\hline
\end{tabular}

${ }^{1}$ Nest densities without taking into account the number of black-headed gull and sand martin nests (the most dense and numerous colonies). 


\subsection{River fragment slightly modified by man (km 394 to $\mathrm{km} \mathrm{421)}$}

Below Dęblin, the Vistula flows within a riverbed only slightly modified by man. (Table 1). It has an appearance typical for a large, lowland braided river with a network of small side channels, steep banks, low sandy bars which are forming dynamically depending on water levels and islands of various sizes and heights with different stages of vegetation succession: from low, flat and only locally growing scarce herbaceous vegetation, through higher, folded, often covered with grass, to high, with numerous bushes and/or trees, mainly willows and poplars. The width of the riverbed is large and ranges from $600 \mathrm{~m}$ to $1500 \mathrm{~m}$. It is a fragment of the Vistula River with the most diverse habitat among the selected ones. At the same time, it is one of the two most valuable sections of the middle Vistula for vertebrates, mainly birds. The five-kilometre-long section of the river between $\mathrm{km} 416$ and $\mathrm{km} 421$ of the waterway was inhabited by at least 27 species of wetland birds during the monitored period, including all threatened species found in the whole monitored area, i.e. the ringed plover, little tern, Eurasian oystercatcher, mew gull, corncrake and hoopoe (Table 2a, b). The overall density of only these species was many times higher than that recorded for the entire avifauna on the man-modified parts of the river, and comparable to the total density of birds on sections of a natural but less diverse habitats (e.g. km 431 to 436, Table 3). General density of wetland avifauna of the riverside is 32.6-45.6 pairs $/ \mathrm{km}$, not including the number of nests in the black-headed gull and sand martin colonies (Table 3 ). If we take this into account, the density of birds is unusually high (337-397 pairs/km along the river), exceeding the figures for primary forests (such as Białowieża Forest), which are considered to be the richest breeding habitats for birds.

\subsection{Vistula Valley fragment largely transformed by man (km 421 to km 426)}

The character of the discussed fragment of the river is strongly influenced by the presence of the Kozienice Power Plant on the left bank. The section of Vistula River between Kochów and Swierże Górne (Kozienice Power Plant, km 421 to $\mathrm{km}$ 426) was almost completely transformed. It is one of the few places in the "Middle Vistula River Valley", except for urban sections (Puławy, Warsaw, Płock), where the river has completely lost its natural character (Table 1). The riverbed here is clearly narrowed and deepened, and the river flows rapidly within one channel. A characteristic element here are numerous concrete groynes and revetments on both banks of the river, and from $\mathrm{km} 423$ onwards, also a concrete bank reinforcement of the power plant. Such a situation almost completely excludes the possibility of birds nesting along the riverside. Only single pairs of lapwings, common sandpipers, little ringed plovers and goosanders, exceptionally also common terns, can be found there (Table 2a, b). The density of birds is very low usually does not exceed 1.0-1.5 pairs $/ \mathrm{km}$ along the river (Table 3 ).

\subsection{River fragment used for extracting gravel and sand from the bottom ( $\mathrm{km} 426$ to km 431)}

Below $\mathrm{km} \mathrm{426,} \mathrm{the} \mathrm{hydrotechnical} \mathrm{facilities}$ on the Vistula are clearly less numerous (single groynes, built at increasing distances from each other, Table 1), and from the middle of $\mathrm{km} 429 \mathrm{~km}$ there are almost no such facilities. A smaller number of facilities regulating the river does not leave the character of the river unaffected, and thus the attractiveness of the site for the breeding avifauna. First kilometres below the power plant (km 426-428) offer birds few convenient breeding habitats. The only potential site to set up a nest is on the right bank, hydrotechnical facilities (revetments) with grass and willow saplings, and sand depositions formed along the bank between adjacent groynes. With each kilometre, the river becomes more and more natural. Below $\mathrm{km} \mathrm{428,} \mathrm{islands} \mathrm{and} \mathrm{sandy} \mathrm{bars} \mathrm{appear.}$ Along the left bank there are also more extensive sand depositions, the right bank is no longer low and covered with trees. In 
the summer of 2007, after the birds finished breeding, between $\mathrm{km} 426$ and $\mathrm{km} \mathrm{428,}$ the extraction of gravel and sand from the bottom of the river started. Eight breeding bird species, including the endangered ringed plover, were found along the aforementioned river fragment (Table 2a). Birds nested at a density of 3.8-4.0 pairs $/ \mathrm{km}$ along the river, i.e. which is almost twice as high as in the case of urban part of the river in Dęblin (Table 3). The ringed plover, settling in the number of three pairs, reached an average density of 0.6 pairs $/ \mathrm{km}$ along the river (Table 2a, Table 3).

\subsection{River fragment slightly modified by man, directly below the gravel and sand extraction point (km 431 to km 436)}

This fragment of the river is similar in character to the fragment between $\mathrm{km} 416$ to $\mathrm{km} 421$ (Table 1). The only difference is a slightly narrower riverbed, a smaller number of sandy bars and islands and a more homogenous character of the habitat. Just like upstream, this is a very important breeding area for birds. In 2007, it was inhabited by 21 wetland bird species at an average density of 12.4-15.8 pairs $/ \mathrm{km}$ along the river (Table 3), and after taking into account the number of nests in the sand martin colonies at a density of $172.4-175.8$ pairs $/ \mathrm{km}$ along the river. Among the threatened species occurring in the whole studied area, the only species whose nest were not found was the Eurasian oystercatcher (Table 2a, b).

\section{Assessment of the impact of gravel and sand extraction from the river on nesting habitats and riparian avifauna}

It is hard to disagree with the opinion that every large-scale development activity in the riverbed of the middle Vistula River brings a potential risk of a negative impact on the fauna and flora, mainly due to the destruction of the natural character of the river and animal and plant habitats both at the project site and in the adjacent areas, especially those located below the project. The range of the negative impact may be different: in case of a small development local, reaching usually up to several hun- dred metres; in case of a large one - up to several or even several dozen kilometres. However, it can be assumed with a high degree of probability that there are also situations when human activity in the riverbed does not adversely affect the natural world, and certainly when these changes have only a slight negative impact on the environment and fauna of the Vistula Valley, and the river does not lose its ability to regenerate its most valuable habitats, i.e. islands and sandy bars in the channel and steep banks. This applies to the sandpit in question. Sand is extracted from the Vistula River between $\mathrm{km} 426$ to $\mathrm{km} 428$ of the waterway, reloading and storage of the extracted material - on the left bank, in the immediate vicinity of the river. This means that there is no negative impact on the riverbed and the precious avifauna that inhabits the Vistula Valley above km 421 of the river (Kot et al. 2009, Table 2a, b). It is also difficult to suppose that the activity could harm the river habitats near the Kozienice Power Plant $(\mathrm{km} 421$ to $\mathrm{km}$ 426). The existing hydrotechnical facilities have changed the river to such an extent that the birds only exceptionally find their place here during the breeding season, and thus there is no fear that they could be affected by the planned development. There are also no grounds to state that the extraction of sand in this site significantly affects the condition of the avifauna in the immediate vicinity of the development

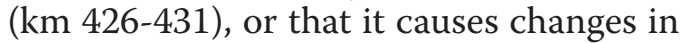
the undeniably precious avifauna, which we note below, i.e. in the part of the river between $\mathrm{km} 431$ and $\mathrm{km} \mathrm{436.} \mathrm{Changes} \mathrm{and}$ condition of wetland avifauna in the period before and several years after the start of this development are shown in Table 4. If we take into account the five-kilometre section of the river where gravel and sand have been mined since 2007, regardless of whether we analyse the number or abundance of the birds in the years 2005-2007, whether eight to ten species (most often nine species) were found here in the years 2008-2010, including one to three endangered species, nesting at an average density 
Table 4. Species richness, abundance and total density (italic) along the river of wetland birds on a 5-km-long fragment of the Vistula River ( $\mathrm{km} 426$ to $\mathrm{km} 431$ of the river) in the years before and after the beginning of sand mining from the riverbed. Threatened species are bolded. Year -2 - two years before sand mining; year $=0$ - a year of the beginning of sand mining (after breeding season of birds); year $+1,+2,+3-$ the second, the third and the fourth year of sand mining.

\begin{tabular}{|c|c|c|c|c|c|}
\hline \multirow[b]{2}{*}{ Species } & \multicolumn{5}{|c|}{$\begin{array}{l}\text { Number of pairs in the Vistula riverbed habitat, } \\
\qquad \mathrm{km} 426 \text { to } \mathrm{km} 431 \text { of the river }\end{array}$} \\
\hline & $\begin{array}{l}2005= \\
\text { year }-2\end{array}$ & $\begin{array}{l}2007= \\
\text { year } 0\end{array}$ & $\begin{array}{c}2008= \\
\text { year }+1\end{array}$ & $\begin{array}{l}2009= \\
\text { year }+2\end{array}$ & $\begin{array}{l}2010= \\
\text { year }+3\end{array}$ \\
\hline $\begin{array}{l}\text { Mew gull } \\
\text { Larus canus }\end{array}$ & 1 & 0 & 1 & 1 & 1 \\
\hline $\begin{array}{l}\text { Common tern } \\
\text { Sterna hirundo }\end{array}$ & $5-8$ & 0 & $5-7$ & $10-12$ & $7-10$ \\
\hline $\begin{array}{l}\text { Little tern } \\
\text { Sternula albifrons }\end{array}$ & $1-2$ & 0 & $4-6$ & 5 & $3-5$ \\
\hline $\begin{array}{l}\text { Little ringed plover } \\
\text { Charadrius dubius }\end{array}$ & 2 & 4 & 1 & $0-1$ & $2-3$ \\
\hline $\begin{array}{l}\text { Ringed plover } \\
\text { Charadrius hiaticula }\end{array}$ & 1 & 3 & 1 & $\mathbf{0}$ & $0-1$ \\
\hline $\begin{array}{l}\text { Lapwing } \\
\text { Vanellus vanellus }\end{array}$ & 3 & 3 & 1 & 2 & 2 \\
\hline $\begin{array}{l}\text { Common redshank } \\
\text { Tringa totanus }\end{array}$ & 2 & 4 & 2 & 1 & 1 \\
\hline $\begin{array}{l}\text { Common sandpiper } \\
\text { Actitis hypoleucos }\end{array}$ & 1 & 1 & 0 & $1-2$ & 3 \\
\hline $\begin{array}{l}\text { Black-tailed godwit } \\
\text { Limosa limosa }\end{array}$ & 0 & 1 & 0 & 0 & 0 \\
\hline $\begin{array}{l}\text { Mallard } \\
\text { Anas platyrhynchos }\end{array}$ & $4-5$ & $2-3$ & $3-4$ & $4-5$ & $3-4$ \\
\hline $\begin{array}{l}\text { Garganey } \\
\text { Anas querquedula }\end{array}$ & 1 & 0 & 0 & $1-2$ & 0 \\
\hline $\begin{array}{l}\text { Goosander } \\
\text { Mergus merganser }\end{array}$ & 0 & 1 & 3 & 2 & $3-4$ \\
\hline $\begin{array}{l}\text { Number of species: } \\
\text { Total (endangered) }\end{array}$ & $10(2)$ & $8(1)$ & $9(2)$ & $9-10(2)$ & $9-10(2-3)$ \\
\hline $\begin{array}{l}\text { Total density: } \\
\text { All species pairs/km } \\
\text { (endangered) }\end{array}$ & $\begin{array}{l}4.2-5.2 \\
(0.2-0.4)\end{array}$ & $\begin{array}{l}3.8-4.0 \\
(0.6)\end{array}$ & $\begin{array}{l}5.0-5.6 \\
(1.0-1.2)\end{array}$ & $\begin{array}{c}5.4-6.6 \\
(1.2)\end{array}$ & $\begin{array}{l}5.0-6.6 \\
(0.8-1.4)\end{array}$ \\
\hline
\end{tabular}


of 3.8-5.0 pairs $/ \mathrm{km}$ (min) to $4.0-6.6$ pairs/ $\mathrm{km}$ (Table 3, Table 4). There were also no significant differences or trends in the species composition of the entire avifauna of the valley (Table 2a, b). The extraction of sand did not affect in any way the species richness and abundance of birds along the fragment of the river below the development. In the year when the project was launched, below $\mathrm{km} 431$ of the waterway, 21 wetland bird species were found, nesting at a density of 12.4-15.8 pairs $/ \mathrm{km}$. After two years of extraction, the site was inhabited by $18-20$ bird species, reaching a density of $13.8-16.8$ pairs $/ \mathrm{km}$ (Table 3 ).

The situation and changes in the avifauna of the inspected sites are influenced not so much by the low harmfulness of this type of development as by its location. It should be stressed that gravel and sand are extracted only over a distance of two kilometres, a largely regulated river, and the part of the river located directly above the sandpit is practically inaccessible to birds (Kozienice Power Plant). This area is a "specific buffer zone" between areas that are attractive and very important for birds and those that cannot be used by birds during the breeding season. With a probability verging on certainty, it can be assumed that in a situation where gravel and sand extraction would take place on a fragment of the river between $\mathrm{km} 393$ to $\mathrm{km} 421$ or below $\mathrm{km} 431$ of the waterway, the negative impact on the breeding habitats and riparian avifauna would be clearly noticeable and, what is worse, probably irreversible.

\section{Importance of the Vistula Valley between km 388 and $\mathrm{km} 436$ of the river for birds during the breeding season}

Taking into account the condition of the avifauna presented in Table 2a, b and Table 3 , there is no doubt that the section of the

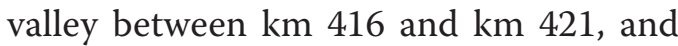
$\mathrm{km} 431$ and $\mathrm{km} 436$ (a slightly man-modified river with steep banks, numerous islands and sand bars in the channel) is more valuable in terms of fauna than that of the commercial-use area between $\mathrm{km} 426$ and km 431 (a sandpit) and definitely more attractive for birds than the heavily regulated section near the Kozienice Power Plant (km 421 to $\mathrm{km} \mathrm{426).} \mathrm{The} \mathrm{monitored}$ 47-kilometre-long fragment of the valley (Table 1) is currently a unique habitat for birds on an international scale. It is one of the very few places in the world where you can find bird community typical for riverbeds of large, unregulated lowland rivers - a habitat that due to human activity is irretrievably disappearing.

\section{Bibliography}

Bukaciński, Dariusz, and Monika Bukacińska. 2003. "Larus canus Common Gull." In Birds of Western Palearctic Update 5, edited by David Parkin, 13-47. Oxford: Oxford University Press.

Bukaciński, Dariusz, i Monika Bukacińska. 2007. „Mewa pospolita Larus canus.” W Atlas rozmieszczenia ptaków lęgowych Polski 19852004, red. Arkadiusz Sikora, Zenon Rohde, Maciej Gromadzki, Grzegorz Neubauer, i Przemysław Chylarecki, 230-231. Poznań: Bogucki Wydawnictwo Naukowe.

Bukaciński, Dariusz, and Monika Bukacińska. 2009. "Threatened bird species of the middle Vistula River islands: status, necessity for protection and proposed activities." In Theoretical and applied aspects of modern ecology, edited by Janusz Uchmański, 219-239. Warszawa: Wydawnictwo UKSW.

Bukaciński, Dariusz, Jakub Paweł Cygan, Marek Keller, Małgorzata Piotrowska, i Janusz Wójciak. 1994. „Liczebność i rozmieszczenie ptaków wodnych gniazdujących na Wiśle Środkowej - zmiany w latach 1973-1993.' Notatki Ornitologiczne 35(1-2): 5-47.

Dombrowski, Andrzej, Przemysław Nawrocki, Jarosław Krogulec, Sławomir Chmielewski, i Mirosław Rzępała. 1994. „Awifauna bocznych odnóg Wisły środkowej w sezonie lęgowym." Notatki Ornitologiczne 35(1-2): 49-78. Głowaciński, Zbigniew (red.). 2001. Polska Czerwona Księga Zwierząt. Kręowce. Warszawa: Państwowe Wydawnictwo Rolnicze i Leśne.

Gromadzki, Maciej (red.). 2004. Ptaki (cz. II).

Poradniki ochrony siedlisk $i$ gatunków Natura 2000 - podręcznik metodyczny, t. 7-8. Warszawa: Ministerstwo Środowiska.

Keller, Marek, Przemysław Chylarecki, i Wie- 
sław Nowicki. 2000. „Ornitologiczna waloryzacja międzywala Wisły od ujścia Pilicy do ujścia Narwi." W Międzywale Wisty jako swoisty uktad przyrodniczy (odcinek Pilica - Narew). Dokumentacja Geograficzna, red. Jan Marek Matuszkiewicz, i Ewa Roo-Zielińska, 119-132. Warszawa: PAN.

Kot, Henryk, Dariusz Bukaciński, Marek Keller, Andrzej Dombrowski, Patryk Rowiński, i Wojciech Błędowski. 2009. Inwentaryzacja ptaków w granicach Obszaru Specjalnej Ochrony Natura 2000 Dolina Srodkowej Wisty PLB 140004. Warszawa: Raport dla
RDOŚ.

Sidło, Paweł Olaf, Bogumiła Blaszkowska, i Przemysław Chylarecki (red.). 2004. Ostoje ptaków o randze europejskiej w Polsce. Warszawa: OTOP.

Wesołowski, Tomasz, Ewa Głażewska, Lech Głażewski, Beata Nawrocka, Przemysław Nawrocki, i Krystyna Okońska. 1984. „Rozmieszczenie i liczebność ptaków siewkowatych, mew i rybitw gniazdujących na wyspach Wisły środkowej." Acta Ornithologica 20: 159-185. 